\title{
Affinity of the Words in Languages Spoken in the Asian and European Countries
}

\author{
Dr. Mohd Shafique* \\ India
}

\begin{abstract}
Language is the way which unites to the man's culture, social and religious life. In the modern worlds various languages are spoken. Every language has its own history and its own area of influence. But one thing is that some languages are related to each other. In ancient India languages were based on tribes' languages. It was noticed that some ancient languages presented striking similarities: Greek and Latin are a well-known example. During classical antiquity it was noted, for example, that Greek héks "six" and heptá "seven" were similar to the Latin sex and septem. Furthermore, the regular correspondence of the initial $h$-in Greek to the initial s- in Latin was pointed out.
\end{abstract}

About the time when the Aryans invaded India, tribes speaking the same language immigrated into Europe and settled in Greece, different tracts of Scandinavia, Germany and Italy, the seat of Imperial Rome. One of the western offshoots founded the Persian monarchy, while another stock settled in Spain and ancient England. Modern linguistic researches have established the unity of the great Aryan family from Ceylon to Greet Britain and Scandinava, from the farthest north to the equator. The Brahmins, the Rajputs and the English are alike the descendants of the ancient Aryans. ${ }^{\text {I }}$

In this paper we have tried to justify some words which are pronounced similarity in the various different languages and their meaning also remains same. On the basis of these words, it also tries to shows the similarities of European and Asian people to each other.

\section{SUMMARY}

The Indo-European proto-languages themselves evolved, each giving rise to its own family of languages. Each family is identified with the proto-language from which it sprung; these families are conventionally listed in order, roughly from west to east with respect to the homelands their speakers came to occupy.

In point of physiognomy the Aryans of India bear a close resemblance to their brothers of the West. They once spoke Sanskrit in its rude form and are still acquainted with that language. Modern philologists have proved the common origin of the Sanskrit with learned languages of the west. ${ }^{2}$ During and after the Renaissance, the close similarities between more languages were also noted, and it was understood that certain groups of languages were related, such as Icelandic and English, and also the Romance languages. Despite all of these observations, the science of linguistics did not develop much further until the 18th century CE. Some languages immigrated into Europe and settled in Greece, different tracts of Scandinavia, Germany, Italy and the seat of Imperial Rome. ${ }^{3}$

The mutual relationship of the Aryan, Greek, Latin, Litto-Sclavonian, Germanic and Celtic languages proves, beyond doubt, the affinity of the nations who speak them. The words are our common in heritance, the relics of antiquity, descended to us from our forefather in ages gone by; and, as coins helps us in deciphering the landmarks of ancient history, so do languages and the words which, like coins, we exchange in our daily avocations and the necessary intercourse of life.

\footnotetext{
* C/O, Department of History, Punjabi University, Patiala

${ }^{1}$ Syad Muhammad Latif, History of the Panjab, Calcutta, 1891, reprint in Delhi, 1992, p.26

${ }^{2}$ Ibid

${ }^{3}$ Edward B. East wick, Handbook of the Punjab Western Rajputana, Kashmir and upper Sindh, London, 1883, p.5
} 
We have all a common fund of words for the members of the family, for cattle, carts, wagons, boats implement of husbandry, metals, vessels, tools and weapons. The close resemblance of even modern Indian languages to those of the West is, in some instances, striking. Thus, we recognize, in the Persian words Punjab (the five rivers) $I I_{E V T E}$, of the Greek, the aber of modern Welsh, in doab (space between two rivers), the Greek $d v o$ or the Latin $d u o$ and the same in Walsh. In raja, Sanskrit, the Latin rex, in badnam Persian, the bad name of English, all most without change. ${ }^{4}$ The warm of English is the waram, of old Geraman, werm of old Dutch, formus of old Latin, OEPuos of Greek, garm of Persian and gharma of Sanskrit. Father, English, is fader in Gothic, vader in Dutch, vater German, pater, Latin, padar, Persian, pita, Sanskrit, bap Urdu. For mother English, we have the Icelandic mother, Danish and Swedish, moder, old Germanic muotar, muatar, Latin, mater, Sanskrit, mata, Persian, madar, old Sclavonicmati, Russian maty, Irish mathaig, Italian, Spanish and Portuguese mader, French mere, and Urdu man. The case is the same with brother, sister, and many other words commonly used in daily life. ${ }^{5}$ The English word widow is derived from two Sanskrit words, $v i$ and dhava (vidhava), vi meaning without and dhava meaning husband. It is in German wedewe, witawa, witwa; Prussian widdewa, Latin vidua, from viduus, bereft of a husband. Similarly, the word daughter is derived from the Sanskrit word duhitri, meaning a 'milkmaid', that being the special part of the domestic economy which fell to the share of a daughter among the Aryans. In Dutch it is dogter, dochter, Icelandic dottir, Swedish dotter and datter, Gothic dauhtar, ${ }^{6}$ Persian dukhtar. ${ }^{7}$ The close similarity between the Dutch and Persian words is most striking. The Indian deva, the bright one, from div, to shine, is the Latin deitas, from dues God, or divas, diusbelonging to a deity, Lithuanian deuas, French deite, Spanish deidad, Portuguese deidade, Italian deita. It recurs as the Zeus (dyaus) of the Greeks and the Jupiter (dyauspitar) of the Romans. All employ cognate words for the processes of household industry and domestic economy. Sewing, fastening together with a needle and thread, is in Urdu sina and in Latin surere. There are cognate terms for the divisions of the year according to the moon, the elementary numbers, yards, gardens, citadels, gods, myths, sacrifices and customs. The Osiris and Isis of Egyptian mythology are the Iswara and Isar of the Hindus, and what is Mitra in the Hindu Veda is Mithra in the Iranian Avesta. The Aryan Varuna, god of the upper air, is the Quranos of the Greeks. The Iranian Vereta, chief of evil spirits, is the Indian Vritra. The word gitar in Hindi, guitar in English, guitare in French. ${ }^{8}$

Above all these words mostly pronouns in same volume in different languages in different countries. During the British colonial expansion into India, a British orientalist and jurist named Sir William Jones became familiar with the Sanskrit language. William Jones (1746-1794) was also knowledgeable in Greek and Latin and was surprised by the similarities between these three languages. During a lecture on February 2, $1786 \mathrm{CE}$, Sir William Jones expressed his new ideas: that 'Sanskrit, Greek, Latin, Persian, Gothic, Celtic etc, had a common origin.'

\section{CONClusion}

What does this mutual relationships of words spoken by nations separated by remote distances from one another prove? It proves two things: first, that the nations which possess and use these words have a common descent in both the Continents of Europe and Asia that they have sprung from common stock. The Greek, the Latin and Teutonic languages are related to the Sanskrit and the ancient Iranian exactly in the same way as these European languages are closely related to each other; in other words, they are sister languages. Secondly, it proves that, even before these nations had separated, they had attained to a certain degree of civilization; they tilled fields, reared cattle, used tools, built houses, wagons and boats.

The idea that Greek, Latin, Sanskrit, and Persian were derived from a common source was revolutionary at that time. This was a turning point in the history of linguistics. ${ }^{10}$ Rather than the

\footnotetext{
${ }_{5}^{4}$ Syad Muhammad Latif, History of the Panjab, p.26

${ }^{5}$ Ibid

${ }^{6}$ L.M.Josi and Fauja Singh (ed) History of the Punjab, Patiala, 2000, p.76

${ }^{7}$ SyadMuhaamad Latif, History of the Panjab, p.26

${ }^{8}$ W.R.Rishi, Multilingual Romani Dictionary, Chandigarh, 1985, p,7

${ }^{9}$ L.M.Josi and Fauja Singh (ed) History of the Punjab, vol, I, p.78

${ }^{10}$ Cristian Violatti, (editors), Ancient History Encyclopedia, Archaeology Department, University of Leicester, England.2015
} 
"daughter" of Greek, Latin was for the first time understood as the "sister" of Greek. By becoming familiar with Sanskrit, a language geographically far removed from Greek and Latin, and realizing that chance was an insufficient explanation for the similarities between these languages, Sir William Jones presented a new insight which triggered the development of modern linguistics.

\section{REFERENCES}

Syad Muhammad Latif, History of the Panjab, Calcutta, 1891, reprint in Delhi, 1992, p.26

Ibid

Edward B. East wick, Handbook of the Punjab Western Rajputana, Kashmir and upper Sindh, London, 1883, p.5

Syad Muhammad Latif, History of the Panjab, p.26 Ibid

L.M.Josi and Fauja Singh (ed) History of the Punjab, Patiala, 2000, p.76

SyadMuhaamad Latif, History of the Panjab, p.26

R.Rishi, Multilingual Romani Dictionary, Chandigarh, 1985, p,7

L.M.Josi and Fauja Singh (ed) History of the Punjab,vol, I, p.78

Cristian Violatti, (editors), Ancient History Encyclopedia, Archaeology Department, University of Leicester, England.2015

\section{AUTHOR's BIOGRAPHY}

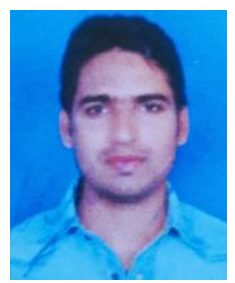

Dr. Mohd.Shafique, Independent Researcher, Completed his Ph.d Titled " Syad Muhammad Latif's writing's on History of Punjab " from Department of History, Punjabi University, Patiala. The main interest area of research based on Historiography and author also contributed many articles in this area. 